\title{
Cefotaxime and Benzyladenine Improve Melon Regeneration
}

\author{
Davood Naderi 1*, Omid Askari-Khorasgani 1,2, Esmaeil Mahmoudi 3 \\ ${ }^{1}$ Young Researchers and Elite Club, Isfahan (Khorasgan) Branch, Islamic Azad University, Isfahan, Iran \\ ${ }^{2}$ Department of Horticulture, Faculty of Agriculture and Natural Resources, Isfahan (Khorasgan) Branch, Islamic Azad \\ University, Isfahan, Iran \\ ${ }^{3}$ Department of Plant Protection, Faculty of Agriculture and Natural Resources, Isfahan (Khorasgan) Branch, Islamic Azad \\ University, Isfahan, Iran \\ ${ }^{*}$ Corresponding author: Davood Naderi, Department of Horticulture, Faculty of Agriculture and Natural Resources, Islamic Azad University, Isfahan, Iran. \\ Tel: +98-3135354001, Fax: +98-3135354001, E-mail: d.naderi@khuisf.ac.ir
}

Received: November 25, 2014; Revised: October 19, 2015; Accepted: January 05, 2016

Background: Worldwidely cultivated, melon is commercially an important fruit crop, as it is in Iran.

Objectives: Establishment of an efficient in vitro plant regeneration system plays a pivotal role in the plant transformation, hence, the importance of regeneration protocol for Iranian melon (Cucumis melo L. var. Gorgab) has encouraged us to work on in vitro melon regeneration.

Material and Methods: The effect of selective media, including various concentrations of the 6-benzyladenine (BA), cefotaxime, as well as indole-3-acetic acid (IAA) on regeneration of the cotyledonary petioles derived from a 6-day-old in vitro grown seedlings were assessed.

Results: The highest frequency of regeneration rate was recorded at $1.5 \mathrm{mg} \cdot \mathrm{L}^{-1}$ of the BA plus $250 \mathrm{mg} . \mathrm{L}^{-1}$ cefotaxime in addition to $1 \mathrm{mg} . \mathrm{L}^{-1}$ BA plus $1000 \mathrm{mg} . \mathrm{L}^{-1}$ cefotaxime. The highest percentage of the shoot formation (100\%) was recorded at $1 \mathrm{mg} . \mathrm{L}^{-1}$ BA plus $1000 \mathrm{mg} . \mathrm{L}^{-1}$ cefotaxime, while, it was relatively lower (75\%) on than the medium containing 1.5 $\mathrm{mg} . \mathrm{L}^{-1} \mathrm{BA}$ in combination with $250 \mathrm{mg} . \mathrm{L}^{-1}$ cefotaxime. The highest root induction was observed in the medium containing $500 \mathrm{mg} . \mathrm{L}^{-1}$ cefotaxime $+0.1 \mathrm{mg} . \mathrm{L}^{-1}$ IAA. A significant positive influence on roots and leaves formation, as well as their number, in addition to regeneration of shoots was observed as well.

Conclusions: This is the first work reporting an appropriate regeneration procedure for the melon, an Iranian native crop. Keywords: Agrobacterium tumefaciens; Cefotaxime; Cucumis melo; Organogenesis; Regeneration

\section{Background}

Cucumis melo L. is among the melon species that encompasses numerous varieties of the cultivars. The plant commonly grows in the tropical, subtropical, as well as in the warm temperate (hot summer) regions of the globe. Central Asia, particularly Khorasan and Persia (Iran), is believed to be the land of origin and development wherein sweet melons have emerged (1). Despite endeavours for developing protocols for melon genetic transformation over the past recent years, genotype-dependency and the low manipulation efficiency $(0-12.5 \%)$ as yet are the two major factors that interfere with the transformation (2). During 2012, the performance yield of the cantaloupe and other melons by Iran has been estimated around 17682.9 Kg.ha-1 with a total production quantity of 1,450,000 tons. Asia dominates the world's cantaloupe production as well as other melon species. Among the leading countries,
China produces the highest amount, (17,568,700 tonnes), followed by Turkey (1,708,415 tons) tonnes) and Iran (1,450,000 tonnes) (FAO, 2012) (3).

Thus far, there were only few researches conducted regarding melon. To attain mass production and commercially reasonable, a long way is left to go, more examinations are needed to be done and technologies such as gene transfer, in addition to the breeding programs should be undertaken $(4,5)$. Although there were numerous attempts to develop virus-resistant transgenic varieties of the melon, still a successful in vitro protocol is required for regeneration of the transgenic plants.

\section{Objectives}

Through undertaking the present study it was attempted to develop an efficient procedure for improving both the reproducibility and the rate of 
recovery of the stably transformed plants derived from cotyledonary petiole of an Iranian melon species (Local name: Gorgabe's Melon). To establish a reliable and efficient regeneration system, suitable for the proliferation of the transgenic plants, the effects of antibiotics and 6-benzyladenine (BA) on the organogenesis of this native crop was scrutinized.

\section{Materials and Methods}

\subsection{Plant Material and Preparation}

Mature seeds of Cucumis melo var. Gorgab were used as source of explant for the organogenesis induction. Seed coats were removed and the surface was disinfected in the $70 \%$ ethanol for $2 \mathrm{~min}$, followed by $1.5 \%$ sodium hypochlorite solution, containing 2 drops of the Tween-20 per $100 \mathrm{~mL}$ solution for $20 \mathrm{~min}$. Finally, seeds were rinsed four times in the sterile distilled water and cultured on $1 / 2$ MS (Murashige and Skoog) medium (6).

The proximal cotyledon section with its 2-3 mm-long hypocotyl stub of the 6-days-old in vitro grown seedlings were excised as explants, and the apical buds of the seedlings were removed under stereomicroscope ('debudding'). Subsequently, the explants derived from 5-7 $\mathrm{mm}$ of the cotyledonary petioles were incubated abaxial side down on MS medium supplemented with a range of concentrations of BA $\left(0,1\right.$, and $\left.1.5 \mathrm{mg} . \mathrm{L}^{-1}\right)$, and cefotaxime $\left(0,250,500,750\right.$, and $\left.1000 \mathrm{mg} . \mathrm{L}^{-1}\right)$. Regenerated shoots grown in the medium containing $250 \mathrm{mg} . \mathrm{L}^{-1}$ cefotaxime plus $1 \mathrm{mg} . \mathrm{L}^{-1} \mathrm{BA}$ were then subcultured on MS medium supplemented with a range of concentrations of the cefotaxime $\left(0,250\right.$, and $\left.500 \mathrm{mg} . \mathrm{L}^{-1}\right)$ combined with $0.1 \mathrm{mg} . \mathrm{L}^{-1}$ Indole-3-acetic acid (IAA) for root induction. The medium was autoclaved at $121^{\circ} \mathrm{C}$ for $20 \mathrm{~min}$ and the $\mathrm{pH}$ of the medium was adjusted to 5.8 with $1 \mathrm{~N} \mathrm{KOH}$ or $\mathrm{HCl}$ prior to autoclaving. Cultures were incubated in the growth chamber at $25 \pm 1{ }^{\circ} \mathrm{C}$ in a normal $16 \mathrm{~h}$ light and $8 \mathrm{~h}$ dark photoperiod provided by 40-50 $\mu \mathrm{mol} . \mathrm{m}^{-2} . \mathrm{s}^{-1}$ cool-white fluorescent lamps. Each combination of the concentrations were replicated 8 times in the petri dishes $(100 \times 15 \mathrm{~mm})$, with 4 segments in each replication. Explants were sub-cultured onto the same medium every 3 weeks after data collection.

\subsection{Statistical Analysis}

Each treatment was replicated three times. A factorial experiment in a completely randomized design was applied to analyze the data. Analysis of variance (ANOVA) using SAS (version 9.1) was applied for testing data and the difference among the means was compared using LSD test at $\mathrm{P}<0.05$.

\section{Results}

\subsection{Effects of BA and Cefotaxime on Shoot Regeneration and Callus Induction}

Since it has been verified that antibiotics can induce negative effects on the plant tissues and regeneration, selection of the appropriate antibiotic and its concentration for Agrobacterium growth suppression plays a crucial role in a successful Agrobacteriummediated plant transformation. Apart from this, plants sensitivity to the antibiotics is species-dependent by either inhibiting or promoting regeneration $(7,8$ and 9 ). Therefore, in the present investigation the assay was focused on the effects of the BA and cefotaxime on the regeneration of the Cucumis melo var. Gorgab. Interestingly, the obtained results have indicated that application of the cefotaxime in the media has numerous significant positive effects on the bud initiation improvement, shoot regeneration, callus formation, root induction, along with leaf formation (Tables 1 and 2). As shown in the (Table 1), the high frequency of the regeneration rate was obtained in the media containing $1.5 \mathrm{mg} . \mathrm{L}^{-1}$ BA plus $250 \mathrm{mg} . \mathrm{L}^{-1}$ cefotaxime and 1 mg.L. - $^{-1}$ BA plus 1000 mg.L $L^{-1}$ cefotaxime with an average of 9.2 and 9 regenerated shoots per explant respectively. Regarding the callus formation, the medium containing $1 \mathrm{mg} . \mathrm{L}^{-1} \mathrm{BA}$ plus $250 \mathrm{mg} . \mathrm{L}^{-1}$ cefotaxime exhibited the highest callus production (Table 1).

\subsection{Effects of IAA and Cefotaxime on Regenerated Shoots}

As could be seen in the (Table 2), application of cefotaxime did not put forth any phytotoxic effect on the regenerated shoots. In contrast, the percentage of the rooted explants, leaf development, and shoot elongation were improved. By looking at the results presented in the (Table 2), it could be clearly understood that, while, a higher concentration of the cefotaxime plus IAA (500 mg.L-1 and $0.1 \mathrm{mg} . \mathrm{L}^{-1}$ of each) was considerably more influential on the root induction, in contrast, cefotaxime at a concentration of $250 \mathrm{mg} . \mathrm{L}^{-1}$ plus $0.1 \mathrm{mg} . \mathrm{L}^{-1}$ IAA results in both secondary root and leaf formation to a significant higher levels.

\section{Discussion}

\subsection{Effects of BA and Cefotaxime on Shoot Regeneration and Callus Induction}

Cefotaxime belongs to cephalosporins, known as $\beta$ lactams; an antibiotic that prevents bacterial proliferation by inhibiting the cell wall synthesis during bacterial cell division (10). Cephalosporins bind to peni- 
Table 1. Interaction effects of various concentrations of the BA and cefotaxime on shoot induction and callus formation of the $C$. melo following to the 3 weeks of the in vitro culture

\begin{tabular}{|c|c|c|c|c|c|c|c|c|}
\hline $\begin{array}{l}\text { Treatments } \\
\left.\text { BA (mg. }{ }^{-1}\right)\end{array}$ & $\begin{array}{c}\text { Cefotaxime } \\
\left(\mathrm{mg} \cdot \mathrm{L}^{-1}\right)\end{array}$ & $\begin{array}{c}\text { Explant } \\
\text { expansion }\end{array}$ & $\begin{array}{l}\text { Explants forming } \\
\text { buds (\%) }\end{array}$ & $\begin{array}{l}\text { No. of buds } \\
\text { per explant }\end{array}$ & $\begin{array}{l}\text { Explants form- } \\
\text { ing shoots (\%) }\end{array}$ & $\begin{array}{l}\text { No. of shoots } \\
\text { per explant }\end{array}$ & $\begin{array}{c}\text { Callus fresh } \\
\text { weight (g) }\end{array}$ & $\begin{array}{l}\text { Callus } \\
\text { growth }\end{array}$ \\
\hline 0 & 0 & $0 \mathrm{c}$ & $0 \mathrm{c}$ & $0 \mathrm{~d}$ & $0 \mathrm{e}$ & $0 \mathrm{~d}$ & $0 \mathrm{~d}$ & $0 \mathrm{~d}$ \\
\hline 0 & 250 & $1.4 \mathrm{ab}$ & $0 \mathrm{c}$ & $0 \mathrm{~d}$ & $0 \mathrm{e}$ & $0 \mathrm{~d}$ & $0 \mathrm{~d}$ & $0 \mathrm{~d}$ \\
\hline 0 & 500 & $1.6 a b$ & $0 \mathrm{c}$ & $0 \mathrm{~d}$ & $0 \mathrm{e}$ & $0 \mathrm{~d}$ & $0 \mathrm{~d}$ & $0 \mathrm{~d}$ \\
\hline 0 & 750 & $1.8 \mathrm{a}$ & $0 \mathrm{c}$ & $0 \mathrm{~d}$ & $0 \mathrm{e}$ & $0 \mathrm{~d}$ & $0 \mathrm{~d}$ & $0 \mathrm{~d}$ \\
\hline 0 & 1000 & $1.3 b$ & $0 \mathrm{c}$ & $0 \mathrm{~d}$ & $0 \mathrm{e}$ & $0 \mathrm{~d}$ & $0 \mathrm{~d}$ & $0 \mathrm{~d}$ \\
\hline 1 & 0 & $2.6 \mathrm{~b}$ & $100 \mathrm{a}$ & $8.4 \mathrm{~b}$ & $50 \mathrm{~cd}$ & $2.2 \mathrm{c}$ & $3.82 \mathrm{~b}$ & $1.8 \mathrm{~b}$ \\
\hline 1 & 250 & $3.2 \mathrm{a}$ & $100 \mathrm{a}$ & $22.3 \mathrm{a}$ & $66.6 \mathrm{bcd}$ & $8.5 a b$ & $6.33 \mathrm{a}$ & $2.8 \mathrm{a}$ \\
\hline 1 & 500 & $2.9 a b$ & $83.3 \mathrm{ab}$ & $7.6 \mathrm{~b}$ & $75 a b c$ & $6.7 a b$ & $1.8 \mathrm{c}$ & $1.3 \mathrm{c}$ \\
\hline 1 & 750 & $3.1 \mathrm{a}$ & $83.3 \mathrm{ab}$ & $11.1 \mathrm{~b}$ & $66.6 \mathrm{bcd}$ & $5.3 \mathrm{~b}$ & $1.91 \mathrm{c}$ & $1.6 \mathrm{bc}$ \\
\hline 1 & 1000 & $2.5 \mathrm{~b}$ & $100 \mathrm{a}$ & $20.1 \mathrm{a}$ & $100 \mathrm{a}$ & $9 a$ & $1.8 \mathrm{c}$ & $1.4 \mathrm{bc}$ \\
\hline 1.5 & 0 & $2.3 d$ & $100 a$ & $11.1 \mathrm{bc}$ & $41.6 \mathrm{~d}$ & $1.2 \mathrm{c}$ & $2.7 \mathrm{~b}$ & $1.5 \mathrm{c}$ \\
\hline 1.5 & 250 & $3.2 \mathrm{bc}$ & $91.6 \mathrm{ab}$ & $15.7 \mathrm{ab}$ & $75 a b c$ & $9.2 \mathrm{a}$ & $3.4 \mathrm{~b}$ & $2.2 \mathrm{ab}$ \\
\hline 1.5 & 500 & $3.3 a b$ & $75 \mathrm{~b}$ & $11.1 \mathrm{bc}$ & $75 a b c$ & $2.5 \mathrm{c}$ & $3.26 \mathrm{~b}$ & $1.9 \mathrm{abc}$ \\
\hline 1.5 & 750 & $3.7 \mathrm{a}$ & $100 \mathrm{a}$ & $18.2 \mathrm{a}$ & $83.3 \mathrm{ab}$ & $6.2 a b$ & $2.9 \mathrm{~b}$ & $2.3 \mathrm{a}$ \\
\hline 1.5 & 1000 & $2.8 \mathrm{c}$ & $91.6 \mathrm{ab}$ & $9.5 \mathrm{c}$ & $58.3 \mathrm{bcd}$ & $2.8 \mathrm{c}$ & $2 \mathrm{bc}$ & $1.8 \mathrm{bc}$ \\
\hline
\end{tabular}

Explant expansion and Callus growth, 0: without callus,1: Slight regenerative, 2: Moderate, 3: Profuse. Values within column sharing same letters are not statistically different at the level of $5 \%$ probability

Table 2. Effects of the various cefotaxime concentrations combined with the IAA on regeneration of the $C$. melo regenerants following to 3 weeks of the in vitro culture

\begin{tabular}{lccccccc}
\hline Treatment & & $\begin{array}{c}\text { Explants form- } \\
\text { ing roots (\%) }\end{array}$ & $\begin{array}{c}\text { No. root per } \\
\text { glass container }\end{array}$ & $\begin{array}{c}\text { Explants form- } \\
\text { ing leaves (\%) }\end{array}$ & $\begin{array}{c}\text { No. leaf per } \\
\text { glass container }\end{array}$ & $\begin{array}{c}\text { Plantlet length } \\
(\mathbf{c m})\end{array}$ & $\begin{array}{c}\text { No. plantlet shoots } \\
\text { per glass container }\end{array}$ \\
\hline $\begin{array}{l}\text { IAA } \\
\left(\mathbf{m g} \mathbf{L}^{-1}\right)\end{array}$ & $\begin{array}{c}\text { Cefotaxime } \\
\left(\mathbf{m g} \mathbf{L}^{-1}\right)\end{array}$ & & & & & & \\
\hline 0.1 & 0 & $16.6 \mathrm{~b}$ & $0.38 \mathrm{a}$ & $25.6 \mathrm{~b}$ & $0.78 \mathrm{~b}$ & $0.21 \mathrm{~b}$ & $0.68 \mathrm{~b}$ \\
0.1 & 250 & $25 \mathrm{~b}$ & $0.78 \mathrm{a}$ & $58.1 \mathrm{a}$ & $2.09 \mathrm{a}$ & $0.50 \mathrm{a}$ & $1.65 \mathrm{a}$ \\
0.1 & 500 & $41.6 \mathrm{a}$ & $1.27 \mathrm{a}$ & $47.2 \mathrm{ab}$ & $1.21 \mathrm{~b}$ & $0.39 \mathrm{a}$ & $0.84 \mathrm{~b}$ \\
\hline
\end{tabular}

Values within column sharing same letters are not statistically different at $5 \%$ probability level.

cillin-binding proteins, enzymes responsible for synthesis or modifying bacterial cell wall. Binding of the antibiotic inhibits cell wall synthesis and causes bacterial death through enzyme-mediated lysis occuring following to the drug administration that causes death as a result of the defective cell wall formation (11). Although some bacteria contain beta-lactamases, which can inhibit the activity of the antibiotic through hydrolysis of the cyclic amide bonds of the $\beta$-lactam ring, cefotaxime is highly resistant to beta-lactamases produced by the Agrobacterium (12). Several studies have demonstrated either a positive or a negative effect of the antibiotics, such as, cefotaxime on the direct as well as indirect regeneration in a dose-dependent manner varying according to the plant species, type of explant, and culture system.
With regards to the explant position, researchers have stated that young and undifferentiated cells in the proximal zone of hypocotyl may contribute to the rapidity of the regeneration rather than cotyledon section (13). This might be related to the differences in endogenous phytohormone levels in the plant tissues (14) or the meristemic activity of the plant tissue as well, which might be affected by plant growth regulators such as cytokinin (15). Moreover, shoot buds usually arise from the meristematic cells called meristemoids.

The superiority of the cotyledonary petiole explants over other types of explant in Cucumis melo cv. Khatooni from Cucurbitaceae (16), and even Kelussia odoratissima from the Apiaceae family (17) have also been reported. Consistently, our preliminary investiga- 
tion has shown that cotyledonary petiole fragments cultured on the media containing BA, and cefotaxime can exert a strong positive influence on the in vitro regeneration system. Likewise, our results have demonstrated that $1 \mathrm{mg} . \mathrm{L}^{-1} \mathrm{BA}$ in addition to 1000 mg.L $\mathrm{L}^{-1}$ cefotaxime and/or $1.5 \mathrm{mg} . \mathrm{L}^{-1}$ BA plus 250 mg. $\mathrm{L}^{-1}$ cefotaxime would be the best treatments for regeneration of this species, which could be helpful for suppressing Agrobacterium growth as well (Table 1). The different concentration of BA that were reported in studies on melon could possibly be due to the variations in the endogenous hormone levels among the different cultivars. Additionally, different plant genotype and varieties exhibit quite different regeneration rates (18). Explant age and gelling agents may also affect the melon regeneration efficiency (19).

Our results also showed that medium containing 1 mg.L-1 BA plus $250 \mathrm{mg} . \mathrm{L}^{-1}$ cefotaxime was efficient for callus production, producing white and friable callus. As well, our results further indicated that regenerability of the $C$. melo cotyledonary petiole explants were affected by the exogenous application of BA and cefotaxime.

\subsection{Effects of IAA and Cefotaxime on Regenerated Shoots}

The results obtained in this work verify that cefatoxime has a positive influence in regeneration processes of $C$. melo var. Gorgab. The positive impact of the antibiotics may be accounted for their hormonelike effects on the plant tissues, which, can also be affected by the plant growth regulators in the medium in addition to influence on the regeneration and callus growth efficiency (20).

As shown in (Table 2), our results have verified that IAA and cefotaxime have markedly improved root, shoot, and leaf formation, as well as plantlet elongation. Based on our preliminary investigation even $1 / 2$ MS medium without auxin has the potential of the root induction (data not shown). This could be due to the fact that different melon cultivars might respond to the different concentration of the plant growth regulators (18).

Plantlets with a well-developed root system were successfully acclimatized (100\% survival rate) by transplanting them into plastic containers containing peat moss and perlite $(1: 1)$ in the greenhouse under normal condition at ambient temperature of $23 \pm 2^{\circ} \mathrm{C}$, and $70 \%$ relative humidity.

In conclusion, through evaluating the efficiency of BA and cefotaxime on regeneration system, we have established a reliable procedure for proliferation of the transgenic and non-transgenic Iranian melon, which is suitable for boosting the manipulation of the melon transformation for commercial purposes. Medium containing $1 \mathrm{mg} . \mathrm{L}^{-1} \mathrm{BA}$ and $1000 \mathrm{mg} . \mathrm{L}^{-1}$ cefotaxime and/or $1.5 \mathrm{mg} . \mathrm{L}^{-1} \mathrm{BA}$ plus $250 \mathrm{mg} . \mathrm{L}^{-1}$ cefotaxime showed a significant positive effect on regeneration system, which may also be applicable for Agrobacterium elimination. As well, the significant positive effect of the cefotaxime on shoot induction, the striking positive synergistic effects of the cefotaxime along with IAA and BA on bud and root induction, shoot elongation, leaf development, and callus growth were also evident. Therefore, our data seem to suggest the optimal level of BA and cefotaxime, pertinent for regeneration and transformation of the Cucumis melo (L) var. Gorgab.

\section{Acknowledgments}

This research was supported by a research grant (project no. 51755901209015) from the Research Council of the Isfahan (Khorasgan) Branch, Islamic Azad University, Iran.

\section{References}

1. Paris HS, Amar Z, Lev E. Medieval emergence of sweet melons, Cucumis melo (Cucurbitaceae). Ann Bot. 2012; 110(1):23-33. DOI: http://dx.doi.org/10.1093/aob/mcs 098

2. Nunez-Palenius HG, Cantliffe DJ, Huber DJ, Ciardi J, Klee HJ. Transformation of a muskmelon 'Galia' hybrid parental line (Cucumis melo L. var. reticulates Ser.) with an antisense ACC oxidase gene. Plant Cell Rep. 2006;25(3):198-205. DOI: http://dx.doi.org/10.1007/s00299-005-0042-0

3. FAO. FAO Statistical Year book: World Food and Agriculture. Food and Agricultural Organization of the United Nations, Rome. 2012.

4. Fang D, Grumet R. Agrobacterium tumefaciens mediated transformation and regeneration of muskmelon plants. Plant Cell Rep. 1990;9(3):160-164. DOI: http://dx.doi.org/10.1007/ bf00232095

5. Ezura H, Amagai H, Yoshioka K, Oosawa K. Highly frequent appearance of tetraploidy in regenerated plants, a universal phenomenon, in tissue culture of melon (Cucumis melo L.). Plant Sci. 1992;85(2):209-213. DOI: http://dx.doi.org/10. 1016/0168-9452(92)90117-5

6. Murashige T, Skoog F. A revised medium for rapid growth and bioassays with tobacco tissue cultures. Physiol Plantarum. 1962;15(3):473-497. DOI: http://dx.doi.org/10.1111/j.13993054.1962.tb08052.x

7. Silva JD, Fukai S. The impact of carbenicillin, cefotaxime and vancomycin on chrysanthemum and tobacco TCL morphogenesis and Agrobacterium growth. J Appl Hort. 2001;3(1):3-12.

8. Wiebke B, Ferreira F, Pasquali G, Bodanese-Zanettini MH, Droste A. Influence of antibiotics on embryogenic tissue and Agrobacterium tumefaciens suppression in soybean genetic 
transformation. Bragantia 2006;65(4):543-551. DOI: http://dx. doi.org/10.1590/s0006-87052006000400002

9. Choi JY, Shin JS, Chung YS, Hyung NI. An efficient selection and regeneration protocol for Agrobacterium-mediated transformation of oriental melon (Cucumis melo L. var. makuwa). Plant Cell Tiss Org Cult. 2012;110(1):133-140. DOI: http://dx.doi.org/10.1007/s11240-012-0137-6

10. Pollock K, Barfield DG, Schields R. The toxicity of antibiotics to plant cell cultures. Plant Cell Rep. 1983;2:36-39. DOI: http://dx.doi.org/10.1007/BF00269232.

11. Nauerby B, Billing K, Wyndaele R. Influence of the antibiotic timentin on plant regeneration compared to carbenicillin and cefotaxime in concentrations suitable for elimination of Agrobacterium tumefaciens. Plant Sci. 1997;123:169-177. DOI: http://dx.doi.org/10.1016/s0168-9452(96)04569-4

12. Tang H, Ren Z, Krezal G. An evaluation of antibiotics for the elimination of Agrobacterium tumefaciens from walnut somatic embryos and for the effects on the proliferation of somatic embryos and regeneration of transgenic plants. Plant Cell Rep. 2000;19(9):881-887. DOI: http://dx.doi.org/ $10.1007 / \mathrm{s} 002990000201$

13. Curuk S, Elman C, Schlarman E, Sagee O, Shomer I, Cetiner S, Gray DJ, Gaba V. A novel pathway for rapid shoot regeneration from the proximal zone of the hypocotyl of melon (Cucumis melo L.). In Vitro Cell Dev Biol Plant. 2002;38(3):260-267. DOI: http://dx.doi.org/10.1079/ivp2001 259

14. Liu EE, Leung DW, Xia QH, Zheng JR, Peng XX, He XM. Efficient plant regeneration in vitro from cotyledon explants of chieh-qua (Benincasa hispida Cogn. var. chieh-qua). Sci Asia. 2013;39(2):134-138. DOI: http://dx.doi.org/10.2306/ scienceasia1513-1874.2013.39.134

15. Koné M, Koné T, Kouakou HT, Konaté S, Ochatt JS. Plant regeneration via direct shoot organogenesis from cotyledon explants of Bambara groundnut, Vigna subterranea (L.) Verdc. Biotechnol Agron Soc Environ. 2013;17(4):584-592.

16. Naderi D, Mousavi A, Habashi AA, Lotfi M. Optimization of somatic embryogenesis induction in Iranian melon (Cucumis melo cv. Khatooni). African J Biotech. 2011;10(34):64346438. DOI: http://dx.doi.org/10.5897/AJB10.1260

17. Askari-Khorasgani O, Mortazaeinezhad F, Otroshy M, Golparvar AR, Moeini A. Direct regeneration of an endangered medicinal plant Kelussia odoratisima. Intl J Agri Crop Sci. 2013;5(17):1969-1974.

18. Ficcadenti N, Rotino GL. Genotype and medium affect shoot regeneration of melon. Plant Cell Tiss Org Cult. 1995;40(3):293295. DOI: http://dx.doi.org/10.1007/bf00048137

19. Souza FVD, Garcia-Sogo B, Souza ADS, San-Juán AP, Moreno V. Morphogenetic response of cotyledon and leaf explants of melon (Cucumis melo L.) cv. Amarillo Oro. Braz Arch Biol Tech. 2006;49(1):21-27. DOI: http://dx.doi.org/10.1590/s1516-89132 006000100003

20. Mathias RJ, Boyd LA. Cefotaxime stimulates callus growth, embryogenesis and regeneration in hexaploid bread wheat (Triticum aestivum L. em. thell). Plant Sci. 1986;46(3):217223. DOI: http://dx.doi.org/10.1016/0168-9452(86)90195-0 